\title{
Adult-only exposure of male rats to a diet of high phytoestrogen content increases apoptosis of meiotic and post-meiotic germ cells
}

\author{
Stephen Assinder, Ryan Davis, Mark Fenwick and Amy Glover \\ Department of Anatomy and Structural Biology, School of Medical Sciences, University of Otago, PO Box 913, \\ Dunedin, New Zealand \\ Correspondence should be addressed to S Assinder is now at Discipline of Physiology, School of Medical Sciences, University \\ of Sydney, NSW 2006, Australia; Email: stephena@physiol.usyd.edu.au
}

\begin{abstract}
Apoptosis plays a critical role in regulating sperm production. Removal of androgens and gonadotropins, or estrogen administration induces germ cell apoptosis. It is hypothesized that dietary phytoestrogens increase apoptosis of developing germ cells, decreasing sperm production. This study aimed to test this in rats fed a high phytoestrogen diet only during adulthood. Male Wistar rats used in this study were offspring of females maintained on a low phytoestrogen diet prior to conception through to weaning. After weaning, juveniles were fed the same low phytoestrogen diet into adulthood. A cohort of males were transferred to a high phytoestrogen diet for 24 days and subsequently testes were collected from all animals. In the high phytoestrogen fed group, homogenization-resistant sperm counts were significantly decreased, as were epididymal sperm counts. Morphometric analysis determined round and elongated spermatid volumes to be significantly decreased, but seminiferous tubule lumen diameters to be significantly increased. TUNEL analysis determined that apoptosis of spermatocytes and round spermatids was significantly greater in the high phytoestrogen fed rats. Neither plasma gonadotropin concentrations nor testicular testosterone were altered. In conclusion, exposure of the adult male rat to a high phytoestrogen diet disrupts spermatogenesis, increasing germ cell apoptosis. This effect is independent of the hypothalamo-pituitary-testicular axis and is likely due to disruption of estrogen's actions in the testis.
\end{abstract}

Reproduction (2007) 133 11-19

\section{Introduction}

Since phytoestrogens were associated with the disruption of mammalian fertility (Moersch et al. 1967), there has been considerable interest in their effects on sexual development and reproductive function. Phytoestrogens are plant-derived compounds and can be divided into three classes, namely isoflavones, coumestans, and lignans. Soybeans, and foods derived from soy, are a rich source of isoflavones that are able to bind and activate estrogen receptors (Kuiper et al. 1997, 1998). Particularly, the binding affinity of estrogen receptor $\beta$ $(E R \beta)$ for the isoflavanoid genistein is $87 \%$ that for estradiol, and genistein activates ER $\beta$ with high potency (Kuiper et al. 1998).

Estrogen is essential for maintenance and normal activity of the male reproductive tract (Eddy et al. 1996, Hess et al. 1997). Exposure to exogenous estrogen or inhibition of endogenous estrogen, either during development or adulthood, induces structural and functional changes in the male reproductive tract. Exposure of neonatal rats to estrogenic chemicals reduces sperm concentrations, plasma testosterone (Goyal et al. 2003, Sharpe et al. 2003), Sertoli cell number (Atanossova et al. 2005), gene expression (Adachi et al. 2004), rete tubule distension, and height of efferent duct epithelium (Aceitero et al. 1998, Fisher et al. 1998, 1999). Similarly, distension of the rete testes, efferent ducts, and epididymides, and subsequent infertility, is seen in ER $\alpha$ null mice (Lubahn et al. 1993, Eddy et al. 1996, Hess et al. 2000). Similar structural and functional abnormalities can be induced by antiestrogen treatment of adult rats (Oliveira et al. 2001), while exposure to low levels of the potent synthetic estrogen diethylstilbestrol (DES) reduces weights of reproductive organs, decreases epididymal sperm, and decreases fertility (Goyal et al. 2001).

Apoptosis of select germ cells occurs normally in the testis and is required to maintain homeostasis (Huckins 
1978, Blanco Rodriguez 1998, Print \& Loveland 2000). Increased apoptosis may be induced following physical or toxicological insult (Richburg 2000). Apoptosis is induced by disruption of the endocrine actions of estrogen by the synthetic DES due to suppression of gonadal testosterone (Nonclerq et al. 1996). ER $\beta$ inactivation decreases apoptosis of spermatogonia in neonatal mice (Delbès et al. 2004), while in adult human testes in vitro estradiol has been shown to inhibit apoptosis of spermatocytes and spermatids (Pentikäinen et al. 2000). Furthermore in aromatase-deficient mice, spermatid development is disrupted with increased germ cell apoptosis (Robertson et al. 1999). This mouse model has also demonstrated that dietary phytoestrogen exposure through a soy-containing rodent feed, influences spermatogenesis independently of the hypothalamo-pituitary-gonadal axis (Robertson et al. 2002).

While many studies have demonstrated the effects of fetal and neonatal phytoestrogen exposure on testis development and subsequent fertility of the adult male (e.g. Tou et al. 1999, Atanassova et al. 2000, Roberts et al. 2000), very few studies have investigated the effects of adult male exposure to dietary phytoestrogens on spermatogenesis, and none have controlled for effects of exposure during the fetal, neonatal, or pubertal periods. This study aimed to test the hypothesis that adult-only exposure of male rats to a diet of high phytoestrogen content disrupts spermatogenesis by increasing germ cell apoptosis.

\section{Materials and Methods}

\section{Diets}

Two diets were used in this study: a low phytoestrogen diet (control) and a high phytoestrogen diet (treatment). The low phytoestrogen diet was Diet 86 (Sharpe, Palmerston North, New Zealand) containing (w/w) $78.8 \%$ cereal, $1.5 \%$ skimmed milk, $7 \%$ fish meal, $6 \%$ bone meal, $0.5 \% \mathrm{NaCl}, 0.1 \%$ rodent premix, and $1 \%$ soy meal. The total phytoestrogen content of the low phytoestrogen diet was $112 \mu \mathrm{g} / \mathrm{g}$ comprised of $53.5 \mu \mathrm{g} / \mathrm{g}$ genistein, $32.5 \mu \mathrm{g} / \mathrm{g}$ daidzin, and $26 \mu \mathrm{g} / \mathrm{g}$ glycitein. The high phytoestrogen diet was Diet RMH 3500 (Reliance Stockfoods, Dunedin, New Zealand) and is the rat chow routinely used in our facilities. It contained (w/w) $61 \%$ cereal, 3.5\% skimmed milk, $2.5 \%$ fish meal, $7.5 \%$ meat/bone meal, $0.4 \% \mathrm{NaCl}$, $0.3 \%$ rodent premix, and $25 \%$ soy meal. The total phytoestrogen content of the high phytoestrogen diet was $465 \mu \mathrm{g} / \mathrm{g}$ made up of $225 \mu \mathrm{g} / \mathrm{g}$ genistein, $180 \mu \mathrm{g} / \mathrm{g}$ daidzin, and $60 \mu \mathrm{g} / \mathrm{g}$ glycitein. Concentrations of isoflavones are the sum of individual isomers, as determined by an independent analysis by the Department of Food Science and Human Nutrition, lowa State University.

\section{Animals}

This study was approved by the Otago University Animal Ethics Committee. To exclude developmental effects of phytoestrogen exposure, all male Wistar rats used in the experiments were bred from females fed the low phytoestrogen diet for 3 weeks prior to mating, and during pregnancy and lactation. The offspring were weaned onto the low phytoestrogen diet and maintained on this diet until adulthood (90 days old) when included in the study. The rats were group housed with others of the same sex and kept under a $12 \mathrm{~h}$ light: $12 \mathrm{~h}$ darkness cycle and had food and water available ad libitum. At 90 days of age, the male rats were assigned either to the control group $(n=8)$, and continued to be fed a low phytoestrogen diet, or to the experimental group $(n=6)$ which were transferred to the high phytoestrogen diet for further 24 days. Animals were then killed by $\mathrm{CO}_{2}$ inhalation. Trunk blood was collected in heparinized tubes, centrifuged to separate plasma from the hematocrit, and the plasma stored at $-30{ }^{\circ} \mathrm{C}$. Testes and epididymides were removed and fat was discarded. Tissue was then weighed, flash-frozen in liquid nitrogen, and stored at $-70{ }^{\circ} \mathrm{C}$. One testis from each animal was post-fixed by thawing in 10\% neutral buffered formalin for $24 \mathrm{~h}$ and transferred to $70 \%$ ethanol for $24 \mathrm{~h}$. These were then embedded in paraffin wax in an orientation to yield cross-sections of seminiferous tubules and processed for morphological analysis and TUNEL assays.

\section{Testicular and epididymal sperm counts}

A sample of each frozen testis was excised on ice, fibrous capsule removed and remaining tissue weighed, and minced in $1 \mathrm{ml} 0.9 \%(\mathrm{w} / \mathrm{v})$ saline for $90 \mathrm{~s}$ using two razor blades according to the method of Taylor (Taylor et al. 1985). Epididymides were thawed on ice and minced as per testes samples. Homogenization-resistant sperm were counted in a hemocytometer, with the average count of ten individual $0.1 \mu \mathrm{m}^{3}$ divisions for three separate aliquots of each suspension being determined, giving a count variation of $<5 \%$.

\section{Plasma gonadotropin determination}

The concentrations of plasma luteinizing hormone ( $\mathrm{LH})$ and follicle-stimulating hormone (FSH) were determined by RIA as previously described (Nicholson et al. 1991), with limits of detection of 0.12 and $0.5 \mathrm{ng} / \mathrm{ml}$ respectively. Both control and experimental samples were measured in triplicate with a coefficient of variation (CV) of $14.06 \%$ for $\mathrm{LH}$ and $17.54 \%$ for $\mathrm{FSH}$.

\section{Testicular testosterone determination}

Samples from each testis were excised on ice and capsule removed, weighed, minced, and homogenized 
in $70 \%(\mathrm{v} / \mathrm{v})$ methanol in glass tubes. The tubes were left at $4{ }^{\circ} \mathrm{C}$ overnight and then centrifuged at $3000 \mathrm{~g}$ for $30 \mathrm{~min}$ at $4{ }^{\circ} \mathrm{C}$. The supernatant was transferred to a fresh glass tube, dried, and extract resuspended in $1 \mathrm{ml}$ testosterone buffer $\left(0.158 \mathrm{~mol} / / \mathrm{Na}_{2} \mathrm{HPO}_{4}, 0.044 \mathrm{~mol} / \mathrm{l}\right.$ $\mathrm{NaH}_{2} \mathrm{PO}_{4} \cdot \mathrm{H}_{2} \mathrm{O}, 0.154 \mathrm{~mol} / \mathrm{l} \mathrm{NaCl}, 0.015 \mathrm{~mol} / \mathrm{l} \mathrm{NaN}$, and $0.1 \%(\mathrm{w} / \mathrm{v})$ gelatin $(\mathrm{pH} 7.2))$ overnight at $4{ }^{\circ} \mathrm{C}$. Testosterone was measured by RIA as previously described (Yeung et al. 1988). The antiserum used was 85/6 (Department of Anatomy, University of Bristol, Bristol, UK). The limit of detection was $50 \mathrm{pg} / \mathrm{ml}$ with a CV of $7.04 \%$.

\section{Morphometric analyses}

Point counting was used to measure volume density $\left(V_{v}\right)$ of seminiferous tubules and interstitium according to Ebling et al. (2000). The observer was blinded to all treatment groups prior to measures being made. Briefly, sections were cut at $5 \mu \mathrm{m}$, de-waxed in xylene, rehydrated in graded alcohol, stained with hemotoxylin and viewed under bright field using a $\times 10$ objective with an Olympus BX50 microscope with SpotR digital camera. Sixteen fields of view per whole section from each animal were randomly selected by a preprogrammed snake pattern $(3 \times 3 \mathrm{~mm}, x$ - and $y$-axis widths) of automatic stage movement (Prior Optiscan, Prior Scientific Instruments, Cambridge, UK). Each field was overlain with a square grid $(7 \times 7)$ with 49 intersects, and the number of superimposed intersects for each component counted. $V_{v}$ was determined as a percentage of the total number of superimposed intersects counted. Volumes per testis were then calculated from testis weight. Seminiferous tubule and lumen diameters were determined from the average distance across the $x$ - and $y$-axes of at least 100 tubules per animal.

The volume density of Sertoli cell nuclei, spermatogonia, spermatocyte, and round and elongated spermatid nuclei was determined by the point counting method as mentioned previously, but with the following modifications. Five micrometer thin sections were stained with Hoescht $33342(10 \mathrm{mg} / \mathrm{ml}(\mathrm{w} / \mathrm{v})$; Molecular probes, Eugene, Oregon, USA). Sections were illuminated at $\lambda 340-385 \mathrm{~nm}$ and viewed under a $\times 40$ objective with an Olympus BX50 microscope with SpotR digital camera. At least ten fields of view were randomly chosen by a pre-programmed snake pattern $(1 \times 1 \mathrm{~mm}, x$ - and $y$-axis widths) of automatic stage movement (Prior Optiscan) and overlain with a $19 \times 15$ grid of 225 intersects.

\section{Quantification of germ cell apoptosis}

Apoptotic germ cells were quantified after the method of Sharpe et al. (1998). Briefly, apoptotic DNA fragmentation in germ cells was detected in $5 \mu \mathrm{m}$ thin testes sections by TUNEL assay according to the manufacturer's instructions (In situ Cell Death Detection Kit, peroxide detection POD: Roche Diagnostics $\mathrm{GmBH}$ ). Negative controls were included by the omission of $3^{\prime}$-end labeling by terminal deoxynucleotidyl transferase. Positive controls were performed by treatment of sections with $1 \mathrm{U} / \mathrm{ml}$ DNase I in $10 \mathrm{mmol} / \mathrm{I}$ Tris- $\mathrm{HCl}(\mathrm{pH} 7.4)$ at $37{ }^{\circ} \mathrm{C}$ for $30 \mathrm{~min}$ prior to terminal end labeling. Sections from each animal were viewed under bright field using a $\times 40$ objective, and scored by an observer blinded to the treatment groups. At least ten fields of view were randomly chosen by a pre-programmed snake pattern $(1 \times 1 \mathrm{~mm}, x$ - and $y$-axis widths) of automatic stage movement (Prior Optiscan) and overlain with a $19 \times 15$ grid of 225 intersects. Points falling over apoptotic or nonapoptotic spermatogonia, spermatocytes, and round and elongated spermatids were counted, expressed as a percentage of the 225 intersects and relative volumes per testis determined from testis weight. The proportion of total apoptotic germ cells was calculated as a ratio of germ cell volume and, similarly, ratios of apoptotic:nonapoptotic spermatogonia, spermatocytes, and round and elongated spermatids were determined (apoptotic indices).

To determine if any changes in germ cell apoptosis induced by dietary regimens was spermatogenic stage dependent, tubule cross-sections for each stage groupings of I-V, VII-VIII, and IX-XIV were scored by counting the number of apoptotic cells per tubule and the mean number of cells per tubule for each stage calculated (Atanassova et al. 1999). For each rat, ten tubules per stage group were scored.

\section{Statistical analysis}

Data are expressed as mean \pm s.E.M. Significant differences between treatment groups were tested by one-way ANOVA furnished by VassarStats statistical computation website (http://faculty.vassar.edu/lowry/vassarstats.html). The significance level was set at $P \leq 0.05$.

\section{Results}

\section{Testicular and epididymal sperm counts}

The number of homogenization-resistant sperm was significantly reduced $(P<0.001)$ in testes of adult male rats that had been transferred to the high phytoestrogen diet (Fig. 1A). Epididymal sperm counts were also significantly lower $(P<0.05)$ in the high phytoestrogen fed group (Fig. 1B).

\section{Gonadotropin and testosterone concentrations}

No differences in testicular testosterone concentrations were measured between the two treatment groups. Similarly, plasma LH and FSH were not different (Table 1). 

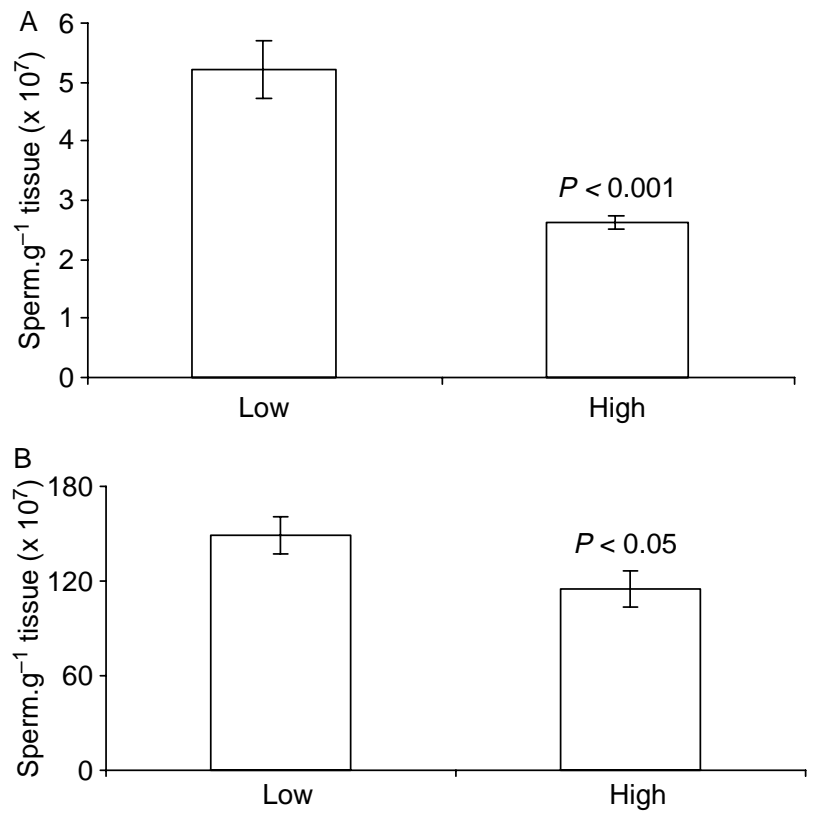

Figure 1 Mean ( \pm S.E.M.) number of homogenization-resistant sperm in testes (A) and ( \pm S.E.M.) epididymides (B) of adult male Wistar rats fed a low phytoestrogen (low; $n=8$ ) or a high phytoestrogen (high; $n=6$ ) diet for 24 days.

\section{Morphometry}

Dietary regimen neither altered the volume of the testis occupied by either the seminiferous tubules or the interstitium, nor did it affect tubule diameter (Table 2). However, tubule lumen diameter was significantly larger in the high phytoestrogen fed group $(P=0.05$; Table 2$)$. Point counting determined no significant differences in nuclear volumes of Sertoli cells, spermatogonia, or spermatocytes between rats fed a low phytoestrogen diet and those fed a high phytoestrogen diet. In contrast, nuclear volume of round and elongated spermatids was significantly lower ( $P=0.021$ and $P=0.007$ respectively) in those rats fed a high phytoestrogen diet (Table 2).

\section{Apoptosis}

TUNEL analysis was used to quantify apoptosis of distinct cell types. Immunoreactive cells were absent in negative control sections while many immunoreactive cells were determined in DNase-treated, positive control sections (data not shown). TUNEL-labeled germ cells were detected in both treatment groups. The ratio of

Table 1 Mean concentrations ( \pm s.E.M.) of testicular testosterone, plasma luteinizing hormone ( $\mathrm{LH})$, and plasma follicle-stimulating hormone of adult rats fed a diet of low phytoestrogen content (low; $n=8$ ) or high phytoestrogen content (high; $n=6$ ) for 24 days.

\begin{tabular}{lccc}
\hline & Testosterone $(\mathrm{ng} / \mathrm{g}$ tissue) & LH $(\mathrm{ng} / \mathrm{ml})$ & FSH $(\mathrm{ng} / \mathrm{ml})$ \\
\hline Low & $27.3(3.9)$ & $1.06(0.47)$ & $8.45(0.82)$ \\
High & $28.0(4.4)$ & $1.34(0.29)$ & $8.07(0.85)$ \\
\hline
\end{tabular}

Table 2 Body, testes, and epididymal weights and morphometric measures of testes of adult male rats fed a low phytoestrogen diet (low; $n=8$ ) or high phytoestrogen diet (high; $n=5$ ) for 24 days.

\begin{tabular}{lccc}
\hline & Low & High & $\boldsymbol{P}$ \\
\hline Body weight $(\mathrm{g})$ & $565 \pm 13$ & $567 \pm 15$ & 0.461 \\
Testis weight $(\mathrm{g})$ & $1.31 \pm 0.04$ & $1.30 \pm 0.08$ & 0.453 \\
Epididymal weight $(\mathrm{g})$ & $0.49 \pm 0.01$ & $0.48 \pm 0.02$ & 0.469 \\
Tubule volume $\left(\mathrm{mm}^{3}\right)$ & $874 \pm 24$ & $880 \pm 80$ & 0.421 \\
Tubule diameter $(\mu \mathrm{m})$ & $342 \pm 10$ & $339 \pm 10$ & 0.419 \\
Tubule lumen diameter $(\mu \mathrm{m})$ & $169 \pm 11$ & $199 \pm 10$ & 0.050 \\
Interstitial volume $\left(\mathrm{mm}^{3}\right)$ & $406 \pm 21$ & $459 \pm 40$ & 0.116 \\
Sertoli cell volume $\left(\mathrm{mm}^{3}\right)$ & $12.0 \pm 1.8$ & $12.0 \pm 1.5$ & 0.500 \\
Spermatogonia volume $\left(\mathrm{mm}^{3}\right)$ & $45.9 \pm 4.6$ & $45.0 \pm 3.9$ & 0.444 \\
Spermatocyte volume $\left(\mathrm{mm}^{3}\right)$ & $69.1 \pm 4.7$ & $70.0 \pm 4.3$ & 0.447 \\
Round spermatid volume $\left(\mathrm{mm}^{3}\right)$ & $108 \pm 7.8$ & $77.8 \pm 8.0$ & 0.021 \\
Elongated spermatid volume $\left(\mathrm{mm}^{3}\right)$ & $116 \pm 8.7$ & $81.5 \pm 4.8$ & 0.007
\end{tabular}

Data are expressed as total volumes per testis occupied by structures or cell nuclei as calculated from volume densities determined by point counts. Values are given as mean \pm S.E.M. Levels of significance are given, where values of $P \leq 0.05$ are deemed significantly different.

apoptotic germ cells (total) determined by point counting was significantly greater in the high phytoestrogen treatment group $(P<0.001$; Fig. 2). Apoptotic indices calculated for spermatocytes and round spermatids were significantly greater in the high phytoestrogen fed animals $(P<0.001$ and $P<0.01$ respectively), while those of spermatogonia and elongated spermatids in the low and high phytoestrogen diet fed animals were similar (Fig. 2). The increase in apoptosis was not preferential for stage groupings with significantly greater numbers of apoptotic germ cells in seminiferous tubules of the high phytoestrogen fed rats. The numbers of TUNEL positive germ cell nuclei were 9.24 \pm 0.36 and $5.32 \pm 0.31$ in stage $\mathrm{I}-\mathrm{V}$ tubules of high and low phytoestrogen fed rats respectively $(P<0.01)$. In stage VII-VIII tubules, there were $6.08 \pm 0.61$ vs $3.46 \pm 0.32$ (high versus low, $P<0.02$ ) and $9.0 \pm 0.2$ vs $5.17 \pm 0.37$ (high vs low; $P<0.001$ ) TUNEL positive germ cell nuclei in stage IX-XIV tubules. These average numbers are not representative of a particular tubule at a given stage of the seminiferous cycle, but of the groupings scored.

\section{Discussion}

This study aimed to test if adult-only exposure of male rats to a diet of high phytoestrogen content would disrupt spermatogenesis by increasing germ cell apoptosis. The diets used in this study were chosen as they were comparable with those used in previous studies (Weber et al. 2001, Fritz et al. 2002, Wang et al. 2002) where low and high phytoestrogen diets generated plasma concentrations similar to those of Western or Oriental men respectively (Adlercreutz et al. 1993). In this study, the total daily phytoestrogen intake was estimated to be $3 \mathrm{mg} / \mathrm{kg}$ body weight (low diet) and $14 \mathrm{mg} / \mathrm{kg}$ body weight, and is comparable with the study of Wang et al. (2002) where total daily phytoestrogen intake was 


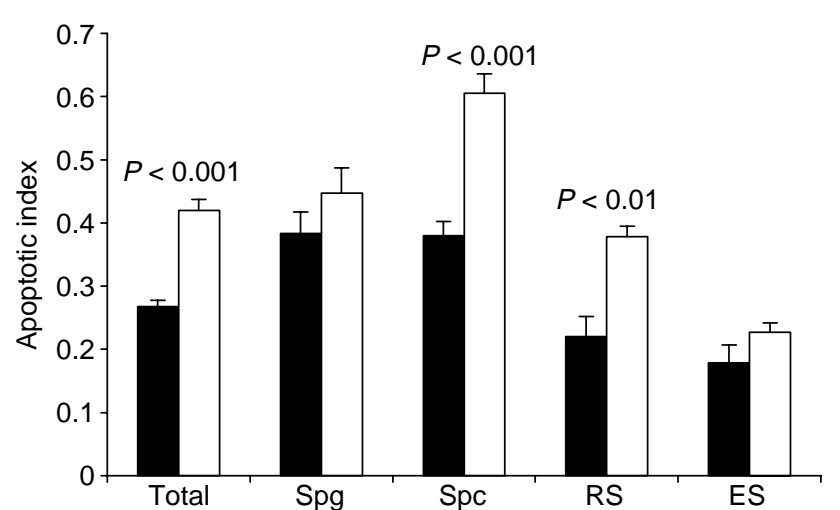

Figure 2 Effects on apoptotic index of a low phytoestrogen (closed bars; $n=8$ ) or high phytoestrogen (open bars; $n=6$ ) containing diet fed to adult rats for 24 days. Values are means ( \pm s.E.M.) for all germ cell types counted (total), and for spermatogonia (Spg), spermatocytes (Spc), round spermatids (RS), and elongated spermatids (ES).

1.8 and $19.25 \mathrm{mg} / \mathrm{kg}$ body weight generating plasma concentrations of 60 and $861 \mathrm{nmol} / \mathrm{l}$ respectively. These levels are much lower than those generated in men by dietary supplements available over the counter (Rannikko et al. 2006).

This study has demonstrated that feeding a diet of high phytoestrogen content to adult rats, not previously exposed to elevated dietary phytoestrogens, disrupts normal spermatogenesis by increasing apoptosis of developing germ cells. Spermatogenesis describes a process of mitotic clonal proliferation, genetic reduction by meiosis, and cell differentiation and remodeling. In order to maintain homeostasis within the testis, apoptosis of developing sperm is required and occurs predominantly in populations of spermatogonia (Huckins 1978, Allan et al. 1992). It is well established that the development of germ cells is dependent on testosterone and $\mathrm{FSH}$, the absence of both hormones increasing germ cell apoptosis (reviewed in McLachlan et al. 1996, 2002). FSH regulates spermatogonial development in the adult rat (Meachem et al. 1998, 1999), testosterone is essential for spermatid development, while both FSH and testosterone are required for spermatocyte development (McLachlan et al. 2002). In this study, neither were there changes in plasma levels of the gonadotropins $\mathrm{LH}$ and $\mathrm{FSH}$, nor were there significant differences in testicular testosterone concentrations. A previous study using a comparable high phytoestrogen diet reported no effects on plasma LH but significantly decreased plasma testosterone (Weber et al. 2001). The discrepancy in testosterone between this study and that of Weber et al. may be due to the longer exposure period used there (35 vs 24 days). No changes in testosterone concentrations have been described in adult-only exposure studies for 3 days (Glover \& Assinder 2006) or 14 days (Fritz et al. 2002). Therefore, increased apoptosis of spermatocytes and round spermatids did not appear to be due to disruption of the hypogonadal-pituitary-testicular axis, consistent with mechanism of action of dietary phytoestrogen in the aromatase null mouse (Roberstson et al. 2002). Furthermore, there was no evidence of stage-dependent changes in apoptosis between the high and low phytoestrogen fed groups. Increased germ cell apoptosis was not restricted to the testosterone sensitive stages VII and VIII (Russell \& Clermont 1977, O'Donnell 1994, Sharpe 1994, Creasy 2001) as significantly increased numbers of apoptotic germ cells occurred in all stage groupings of the spermatogenic cycle in animals fed the high phytoestrogen diet. A similar effect has been demonstrated in rats exposed to estrogen neonatally whereby efficiency of spermatogenesis in adulthood is decreased as germ cell apoptosis, independent of spermatogenic stage, is increased (Atanassova et al. 1999). This was suggested to be an indirect action of estrogen due to decreased fluid resorption in the efferent ducts as evidenced by increased luminal volume of the seminiferous tubules (Atanassova et al. 1999). It is possible that decreased fluid resorption is a factor in this study as tubule lumen diameter was found to be significantly increased in the high phytoestrogen fed animals. Given that there was a decrease in post-meiotic germ cell numbers in this group, one may expect to see a decrease in the testis weight also. However, no difference in testis weight was determined. This may be explained by increased luminal fluid volume in the high phytoestrogen fed animals. Disruption of normal estrogen action by the removal of functional $E R \alpha$ in mice (Eddy et al. 1996, Hess et al. 1997) or administration of an anti-estrogen to adult rats (Oliveira et al. 2001) causes reduced fluid absorption in the excurrent ducts.

Paracrine and/or autocrine actions of estrogen in the rat testis are possible given that: aromatase is present in the rat Leydig cells, Sertoli cells, spermatocytes, and round and elongating spermatids (Levallet et al. 1998); $\mathrm{ER} \alpha$ is expressed in Leydig cells (Pelletier et al. 2000); ER $\beta$ in Sertoli cells (Saunders et al. 1998) and spermatogonia (Saunders et al. 1998, van Pelt et al. 1999); both receptor types are present in spermatocytes and round spermatids (Saunders et al. 1998, Pelletier et al. 2000). A direct role for estrogen in the prevention of human germ cell apoptosis has been described (Pentikäinen et al. 2000). In vitro incubation of seminiferous tubules in serum and hormone-free media induces apoptosis of spermatocytes and spermatids. This apoptosis is inhibited by $17 \beta$-estradiol. This same population of cells exhibit increased apoptosis here when a diet of high phytoestrogen content is consumed. This induction of apoptosis suggests, therefore, that phytoestrogens are anti-estrogenic in this respect. Indeed, in adult aromatase null mice, there is an arrest at the meiotic stage of spermatogenesis causing a significant decrease in the number of round and elongated spermatids (Robertson et al. 1999). Aromatase deficiency does not alter spermatogonial numbers 
(Robertson et al. 1999) nor is estrogen synthesis from testosterone responsible for the testosterone induced restoration of spermatogonial development following $\mathrm{GnRH}$ inactivation (Meachem et al. 2005). This pattern is identical to that induced by the high phytoestrogen diet here. Spermatogonia and spermatocyte volumes were not depleted. As there was no difference in the incidence of apoptotic spermatogonia, this was as expected. A greater incidence of apoptotic spermatocytes was consistent with fewer round spermatids in the high phytoestrogen fed animals. As this would lead to fewer round spermatids progressing to elongating spermatids, and given that there was increased apoptosis of round spermatids, a smaller population would proceed to the elongated spermatid stage. Hence, one would predict fewer elongating spermatids, and hence a reduced testicular sperm count in the high phytoestrogen group, as was found.

A recent study by Anway et al. (2005) has described transgenerational effects of endocrine disruption that are transferred through the male germ line in the rat. Exposure to either the anti-androgen vinclozolin or the estrogenic compound methoxychlor during the period of sex determination and testis development in the rat resulted in increased apoptosis of germ cells and sperm numbers in the $F_{1}$ generation and were still manifest in the $F_{4}$ generation. This transgenerational effect was coincidental to altered DNA methylation patterns of the male germ line induced by endocrine disruption during the re-methylation programming of the germ line that occurs during the period of sex determination (Reik $\&$ Walter 2001). As the male rats used in this study were only exposed to the high phytoestrogen diet at adulthood, the effects here are not due to differences in re-methylation. However, that does not preclude the possibility that there may be epigenetic effects caused by exposure in utero due to feeding pregnant dams a high phytoestrogen diet during embryonic days 12-15, the period of sex determination and testis development. A number of studies have been conducted on the effects of exposure to isoflavones during gestation. Kang et al. (2002) reported no effects on sperm count or motility in males exposed between E10 and PND21 to doses of genistein equivalent to Western diet exposure (low dose). Studies of males continually exposed to dietary genistein, from conception through to adulthood, suggest no difference in the pathology of the male tract (Fritz et al. 2002, You et al. 2002), however, no in depth studies on the effects on spermatogenesis were conducted. As yet, there have been no reports on possible epigenetic effects of exposure to isoflavones during this critical period of re-methylation.

Recent reports of the gradual decline in human semen quality have sparked much debate as to causes/risk factors. Some have suggested that spermatogenesis can be significantly affected by environmental and lifestyle factors that appear to have no other detrimental affect to the health of the individual (reviewed by Sharpe 2000, Sharpe \& Franks 2002). Two such factors associated with adult exposure are seasonality, with demonstrably reduced sperm counts in summer months (Politoff et al. 1989, Saint Pol et al. 1989, Gyllenborg et al. 1999) and scrotal heating (Irvine 1998, Thonneau et al. 1998, Bujan et al. 2000, Hjollund et al. 2000). Dietary effects in adulthood have primarily been associated with women (Sharpe \& Franks 2002). Indeed, dietary phytoestrogen exposure in animals grazing estrogenic pastures has long been known to cause significant impairment of reproductive function (reviewed by Adams 1995). Clover disease, a syndrome of ewes grazing subterranean clover was first described by Bennetts et al. (1946). Temporary and permanent infertility is a factor only evident in females, however, with no apparent disruption of male reproductive function or general health of the noncastrate ram (Adams 1995).

Our findings also contrast previous studies in rats. However, those studies are not comparable either in the dose or in the controlled background from which animals were raised and handled prior to inclusion. A study by Ashby et al. (2003) reported inconsistent effects of diet, demonstrating both significant and nonsignificant decreases in daily sperm production. It was concluded that this inter-experimental variation was due to either inter-animal or random variation, and it was recognized by the authors that the study was confounded by non-controlled factors, such as different animal shipments and variations in animal husbandry. In this study, all animals were bred and raised in-house and all animals were fed an identical diet up until rats were randomly assigned to the high phytoestrogen diet group. In the study of Faqi et al. (2004), an extremely high dose of $2000 \mathrm{mg} / \mathrm{kg}$ total phytoestrogen had no effect on daily sperm production unlike the high phytoestrogen fed animals in this study where a dose of $465 \mathrm{mg} / \mathrm{kg}$ was employed. The reason for this difference is unclear. However, the length of exposure in that study was much longer with measures being made at least 12 months after subjects were transferred to the high phytoestrogen diet. It may be that there is a compensation or induced insensitivity due to such a chronic exposure. Disparity between studies is well known and many factors have been suggested in this (Akingbemi 2005).

The high phytoestrogen diet is that normally used in our animal facilities. As such no detrimental health effects are associated with its use, and Wistar rat fecundity appears normal with an average litter size of 12 pups. Indeed, feeding adult male rats for 24 days with the high phytoestrogen diet does not reduce fecundity per se, even though, as we report here, sperm production is reduced in these animals (Glover \& Assinder 2006). However, we have shown that acute exposure to this diet causes a significantly reduced fecundity, altered expression of steroid receptors in the epididymis, and increased sperm lipid peroxidation (Glover \& Assinder 
2006). Anecdotally, there have been problems with breeding of some transgenic mouse lines (C57Bl/6) background). These problems were rectified by transferring to the low phytoestrogen diet. It is interesting to note that in a study of endocrine disruption of the juvenile male reproductive tract, $\mathrm{C} 57 \mathrm{BL} / 6 \mathrm{~J}$ mice were most sensitive to low-dose estradiol (Spearow et al. 1999).

It is possible that the lower proportion of fish meal in the high phytoestrogen diet could have resulted in lower levels of essential fatty acids (EFA) causing impaired spermatogenesis. Spermatogenesis is impaired in EFAdeficient rats (Evans et al. 1934, Alfin-Slater \& Bernwick 1958) with a loss of spermatocytes. However, this is unlikely to be a factor. The essential fatty acid content of white fish meal is $2.0 \%(\mathrm{w} / \mathrm{w})$, while that of soy meal is $0.4 \%$ (w/w; Food and Agricultural Organizations of the United Nations 1986). On that basis, the essential fatty acid content would be 1.7 and $1.6 \mathrm{mg} / \mathrm{g}$ of the low and high phytoestrogen diets respectively. Therefore, the estimated daily intake of EFA per day for both groups would be in excess of $20 \mathrm{mg} /$ day, twice that needed to restore spermatogenesis in EFA-deficient animals (Alfin-Slater \& Bernwick 1958). Furthermore, rats placed on a fat-free diet at weaning became deficient in EFAs only after 12 weeks (Alfin-Slater \& Bernwick 1958), much longer than the time period here.

In conclusion, adult-only exposure of male rats to a diet of high phytoestrogen content increases germ cell apoptosis reducing testicular sperm numbers. This disruption of spermatogenesis is independent of the hypothalamo-pituitary-testicular axis and is likely to be due to disruption of paracrine and/or autocrine actions of estrogen in the testis.

\section{Acknowledgements}

We thank Dr Peter Hurst for his advice and expertise in the stereological approaches. This work was funded by a University of Otago Research Grant and a Community Trust of Otago annual grant 224. The authors declare that there is no conflict of interest that would prejudice the impartiality of this scientific work.

\section{References}

Aceitero J, Llanero M, Parrado R, Pena E \& Lopez-Beltran A 1998 Neonatal exposure of male rats to estradiol benzoate causes rete testis dilation and backflow impairment of spermatogenesis. Anatomical Record 252 17-33.

Adachi T, Ono Y, Koh K-B, Takashima K, Tainaka H, Matsuno Y, Nakagawa S, Todaka E, Sakurai K \& Fukata H 2004 Long-term alteration of gene expression without morphological change in testis after neonatal exposure to genistein in mice: toxicogenomic analysis using cDNA microarray. Food and Chemical Toxicology 42 445-452.

Adams NR 1995 Detection of the effects of phytoestrogens in sheep and cattle. Journal of Animal Science 73 1509-1515.

Adlercreutz H, Markkanen H \& Watanabe S 1993 Plasma concentrations of phyto-estrogens in Japanese men. Lancet 342 1209-1210.
Akingbemi BT 2005 Estrogen regulation of testicular function. Reproductive Biology and Endocrinology 3 51-74.

Alfin-Slater RB \& Bernwick S 1958 Changes in tissue lipids and tissue histology resulting from essential fatty acid deficiency in rats. American Journal of Clinical Nutrition 6 616-624.

Allan DJ, Harman BV \& Roberts SA 1992 Spermatogonial apoptosis has morphologically recognisable phases and shows no circadian rhythm during normal spermatogenesis in the rat. Cell Proliferation 25 241-250.

Anway HD, Cupp SA, Uzuman M \& Skinner MK 2005 Epigenetic transgenerational actions of endocrine disruptors and male fertility. Science 308 1466-1469.

Ashby J, Tinwell H, Lefevre PS, Joiner R \& Haseman J 2003 The effect of sperm production in adult Sprague-Dawley rats exposed to bisphenol A between postnatal days 91-97. Toxicological Sciences 74 129-138.

Atanassova N, McKinnell C, Walker M, Turner KJ, Fisher JS, Morley M, Millar MR, Groome NP \& Sharpe RM 1999 Permanent effects of neonatal estrogen exposure in rats on reproductive hormone levels, and efficiency of spermatogenesis in adulthood. Endocrinology $\mathbf{1 4 0}$ 5364-5373.

Atanassova N, McKinnell C, Turner KJ, Walker M, Fisher JS, Morley M, Millar MR, Groome NP \& Sharpe RM 2000 Comparative effects of neonatal exposure of male rats to potent and weak (environmental) oestrogens on spermatogenesis at puberty and the relationship to adult testis size and fertility: evidence for stimulatory effects of low estrogen levels. Endocrinology 141 3898-3907.

Atanassova NN, Walker M, McKinnell C, Fisher JS \& Sharpe RM 2005 Evidence that androgens and oestrogens, as well as folliclestimulating hormone, can alter Sertoli cell number in the neonatal rat. Journal of Endocrinology 184 107-117.

Bennetts HW, Underwood EJ \& Shier FL 1946 A specific breeding problem of sheep on subterannean clover pastures in Western Australia. Australian Veterinary Journal 22 2-8.

Blanco Rodriguez J 1998 A matter of death and life: the significance of germ cell death during spermatogenesis. International Journal of Andrology 21 236-248.

Bujan L, Daudin M, Charlet JP, Thonneau P \& Mieusset R 2000 Increase in scrotal temperature in car drivers. Human Reproduction $\mathbf{1 5}$ 1355-1357.

Creasy DM 2001 Pathogenesis of male reproductive toxicity. Toxicologic Pathology 29 64-76.

Delbès G, Levacher C, Pairault C, Racine C, Duquenne C, Krust A \& Habert R 2004 Estrogen receptor $\beta$-mediated inhibition of male germ cell line development in mice by endogenous estrogens during perinatal life. Endocrinology 145 3395-3403.

Ebling FJP, Brooks AN, Cronin AS, Ford H \& Kerr JB 2000 Estrogenic induction of spermatogenesis in the hypogonadal mouse. Endocrinology $1412861-2869$.

Eddy EM, Washburn TF, Bunch DO, Goulding EH, Gladen BC, Lubahn DB \& Korach KS 1996 Targeted disruption of the oestrogen receptor gene in male mice causes alteration of spermatogenesis and infertility. Endocrinology 137 4796-4805.

Evans HM, Lepkovsky S \& Murphy EA 1934 Vital needs of the body for certain unsaturated fatty acids VI. Male sterility on fat free diets. Journal of Biological Chemistry 106 445-449.

Faqi AS, Johnson WD, Morrissey RL \& McCormick DL 2004 Reproductive toxicity assessment of chronic dietary exposure to soy isoflavones in male rats. Reproductive Toxicology 18 605-611.

Fisher JS, Turner KJ, Fraser HM, Saunders PTK, Brown D \& Sharpe RM 1998 Immunoexpression of aquaporin-1 in the efferent ducts of the rat and marmoset monkey during development, its modulation by estrogens, and its possible role in fluid resorption. Endocrinology 139 3935-3945.

Fisher JS, Turner KJ, Brown D \& Sharpe RM 1999 Effect of neonatal exposure to estrogenic compounds on development of the excurrent ducts of the rat testis through puberty to adulthood. Environmental Health Perspectives 107 397-405. 
Food and Agricultural Organisations of the United Nations 1986 The production of fish meal and oil. FAO Fisheries Technical paper 142 http://www.fao.org/DOCREP/003/X6899E/X6899EOO.HTM.

Fritz WA, Wang J, Eltoum IE \& Lamartiniere CA 2002 Dietary genistein down-regulates androgen and estrogen receptor expression in the rat prostate. Molecular and Cellular Endocrinology 186 89-99.

Glover A \& Assinder SJ 2006 Acute exposure of adult male rats to dietary phytoestrogens reduces fecundity and alters epididymal steroid hormone receptor expression. Journal of Endocrinology 189 $565-573$.

Goyal HO, Braden TD, Mansour M, Williams CS, Kamaleldin A \& Srivastava KK 2001 Diethylstilbestrol-treated adult rats with altered epididymal sperm numbers and sperm motility parameters, but without alterations in sperm production and sperm morphology. Biology of Reproduction 64 927-934.

Goyal HO, Robateau A, Braden TD, Williams CS, Srivastava KK \& Ali K 2003 Neonatal estrogen exposure of male rats alters reproductive functions at adulthood. Biology of Reproduction 68 2081-2091.

Gyllenborg J, Skakkebaek NE, Nielsen NC, Keiding N \& Giwercman A 1999 Secular and seasonal changes in semen quality among young Danish men - a statistical analysis of semen samples from 1927 donor candidates during 1977-1995. International Journal of Andrology 22 28-36.

Hess RA, Bunick D, Lee K, Taylor JA, Korack KS \& Lubahn DB 1997 A role for oestrogens in the male reproductive system. Nature 390 509-512.

Hess RA, Bunick D, Lubahn DB, Zhou Q \& Bouma J 2000 Morphologic changes in efferent ductules and epididymis in estrogen receptor- $\alpha$ knockout mice. Journal of Andrology 21 107-121.

Hjollund NH, Bonde JP, Jensen TK \& Olson J 2000 Diurnal scrotal skin temperature and semen quality. The Danish first pregnancy planner study team. International Journal of Andrology 23 309-318.

Huckins C 1978 The morphology and kinetics of spermatogonial degeneration in normal adult rat: an analysis using a simplified classification of the germinal epithelium. Anatomical Record 190 905-926.

Irvine DS 1998 Epidemiology and aetiology of male infertility. Human Reproduction 13 33-44

Kang KS, Che JH \& Lee YS 2002 Lack of adverse effects in the $F_{1}$ offspring maternally exposed to genistein at human intake dose level. Food and Chemical Toxicology 40 43-51.

Kuiper GGJM, Carlsson B, Grandien K, Enmark E, Häggblad J, Nilsson S \& Gustafsson J-A 1997 Comparison of the ligand binding specificity and transcript distribution of estrogen receptors $\alpha$ and $\beta$. Endocrinology 138 863-870.

Kuiper GGJM, Lemmen JG, Carlsson B, Corton JC, Safe SH, van der Saag PT, van der Burg B \& Gustafsson J-A 1998 Interaction of estrogenic chemicals and phytoestrogens with estrogen receptor $\beta$. Endocrinology 139 4252-4263.

Levallet J, Bilinska B, Mittre H, Genissel C, Fresnel J \& Carreau S 1998 Expression and immunolocalization of functional cytochrome P450 aromatase in mature rat testicular cells. Biology of Reproduction $\mathbf{5 8}$ 919-926.

Lubahn DB, Moyer JS, Golding TS, Couse JF, Korach KS \& Smithies O 1993 Alteration of reproductive function but not prenatal sexual development after insertional disruption of the mouse estrogen receptor gene. PNAS 90 11162-11166.

McLachlan RI, Wreford NG, O'Donnell L, de Kretser DM \& Robertson DM 1996 The endocrine regulation of spermatogenesis: independent roles for testosterone and FSH. Journal of Endocrinology 148 1-9.

McLachlan RI, O'Donnell L, Meachem SJ, Stanton PG, de Kretser DM, Pratis K \& Robertson DM 2002 Identification of specific sites of hormonal regulation in spermatogenesis in rats, monkey, and man. Recent Progress in Hormone Research 57 149-179.

Meachem SJ, Wreford NG, Stanton PG, Robertson DM \& McLachlan RI 1998 Follicle stimulating hormone is required for the initial phase of spermatogenic restoration in adult rats following gonadotrophin suppression. Journal of Andrology 19 725-735.
Meachem SJ, McLachlan RI, Stanton PG, Roberston DM \& Wreford NG 1999 FSH immunoneutralization acutely impairs spermatogonial development in normal adult rats. Journal of Andrology 20 756-762.

Meachem SJ, Robertson DM, Wreford NG, McLachlan RI \& Stanton PG 2005 Oestrogen does not affect the restoration of spermatogenesis in the gonadotrophin-releasing hormone-immunised adult rat. Journal of Endocrinology 185 529-538.

Moersch GW, Morrow DF \& Neuklis WA 1967 The antifertility activity of isoflavones related to genistein. Journal of Medicinal Chemistry $\mathbf{1 0}$ 154-158.

Nicholson HD, Guldenaar SEF, Boer GJ \& Pickering BT 1991 Testicular oxytocin: effects of intratesticular oxytocin in the rat. Journal of Endocrinology 130 231-238.

Nonclerq D, Reverse D, Toubeau G, Beckers JF, Sulon J, Laurent G, Zanen J \& Heuson-Stiennon JA 1996 In situ demonstration of germinal cell apoptosis during diethylstilbestrol-induced testis regression in adult male Syrian hamsters. Biology of Reproduction 55 1368-1376.

O'Donell L, McLachlan RI, Wreford NG \& Robertson DM 1994 Testosterone promotes the conversion of round spermatids between stages VII and VIII of the rat spermatogenic cycle. Endocrinology 135 2608-2614.

Oliveira CA, Carnes K, França LR \& Hess RA 2001 Infertility and testicular atrophy in the antiestrogen-treated adult male rat. Biology of Reproduction 65 913-920.

Pelletier G, Labrie C \& Labrie F 2000 Localization of oestrogen receptor $\alpha$, oestrogen receptor $\beta$ and androgen receptors in the rat reproductive organs. Journal of Endocrinology 165 359-370.

Pentikäinen V, Erhkila K, Suomalainen L, Parvinen M \& Dunkel L 2000 Estradiol acts as a germ cell survival factor in the human testis in vitro. Journal of Clinical Endocrinology and Metabolism 85 2057-2067.

Politoff L, Birkhauser M, Almendral A \& Zorn A 1989 New data confirming a circannual rhythm in spermatogenesis. Fertility and Sterility 52 486-489.

Print CG \& Loveland KL 2000 Germ cell suicide: new insights into apoptosis during spermatogenesis. BioEssays 22 423-430.

Rannikko A, Petas A, Rannikko S \& Adlercrutz H 2006 Plasma and prostate phytoestrogen concentrations in prostate cancer patients after oral phytoestrogen supplementation. Prostate 66 82-87.

Reik W \& Walter J 2001 Genomic imprinting: parental influence on the genome. Nature Reviews. Genetics 2 21-32.

Richburg JH 2000 The relevance of spontaneous- and chemicallyinduced alterations in testicular germ cell apoptosis to toxicology. Toxicology Letters 112 79-86.

Roberts D, Veermanchaneni DNR, Schlaff WD \& Awoniyi CA 2000 Effects of chronic dietary exposure to genistein, a phytoestrogen, during various stages of development on reproductive hormones and spermatogenesis in rats. Endocrine 13 281-286.

Robertson KM, O'Donnell L, Jones MME, Meachem SJ, Boon WC, Fisher CR, Graves KH, McLachlan RI \& Simpson ER 1999 Impairment of spermatogenesis in mice lacking a functional aromatase (cyp 19) gene. PNAS 96 7986-7991.

Robertson KM, O'Donnell L, Simpson ER \& Jones MME 2002 The phenotype of the aromatase knockout mouse reveals dietary phytoestrogens impact significantly on testis function. Endocrinology 143 2913-2921.

Russell LD \& Clermont Y 1977 Degeneration of germ cells in normal, hypophysectomized and hormone treated hypophysectomized rats. Anatomical Record 187 347-366.

Saint Pol P, Beuscart R, Leroy-Martin B, Hermond E \& Jablonski W 1989 Circannual rhythms of sperm parameters of fertile men. Food and Chemical Toxicology 51 1030-1033.

Saunders PT, Fisher JS, Sharpe RM \& Millar MR 1998 Expression of oestrogen receptor $\beta$ (ER $\beta$ ) occurs in multiple cell types, including some germ cells, in the rat testis. Journal of Endocrinology $\mathbf{1 5 6}$ R13-R17. 
Sharpe RM 1994 Regulation of spermatognesis. In The Physiology of Reproduction, 2 edn, pp 1363-1434. Eds E Knobil \& JD Neill. New York: Raven Press.

Sharpe R 2000 Lifestyle and environmental contribution to male infertility. British Medical Bulletin 56 630-642.

Sharpe R \& Franks S 2002 Environment, lifestyle and infertility - an intergenerational issue. Nature Cell Biology 4 S33-S40.

Sharpe RM, Atanassova N, McKinell C, Parte P, Turner KJ, Fisher JS, Kerr JB, Groome NP, Macpherson S, Millar MR \& Saunders PTK 1998 Abnormalities in functional development of the Sertoli cells in rats treated neonatally with diethylstilbestrol: a possible role for estrogens in Sertoli cell development. Biology of Reproduction 59 1084-1094.

Sharpe RM, Rivas A, Walker M, McKinnell C \& Fisher JS 2003 Effect of neonatal treatment of rats with potent or weak (environmental) oestrogens, or with a GnRH antagonist, on Leydig cell development and function through puberty into adulthood. International Journal of Andrology 26 26-36.

Spearow JL, Doemeny P, Sera R, Leffler R \& Barkley M 1999 Genetic variation in susceptibility to endocrine disruption by estrogen in mice. Science 285 1259-1261.

Taylor GT, Weiss J, Frechmann T \& Haller J 1985 Copulation induces an acute increase in epididymal sperm numbers in the rat. Journal of Reproduction and Fertility 73 323-327.

Thonneau P, Bujan I, Multigner I \& Mieusset R 1998 Occupational heat exposure and male fertility: a review. Human Reproduction 13 2122-2125.

Tou JCL, Chen J \& Thompson LU 1999 Dose, timing and duration of flax seed exposure affects reproductive indices and sex hormone levels in rats. Journal of Toxicology and Environmental Health $\mathbf{5 6}$ 555-570.

van Pelt MM, de Rooj DG, van der Burg B, van der Saag PT, Gustafsson JA \& Kuiper GJM 1999 Ontogeny of estrogen receptor beta expression in rat testis. Endocrinology 140 478-483.

Wang J, Eltoun IE \& Lamartiniere CA 2002 Dietary genistein suppresses chemically induced prostate cancer in Lobund-Wistar rats. Cancer Letters 186 11-18.

Weber KS, Setchell KDR, Stocco DM \& Lephart ED 2001 Dietary soyphytoestrogens decreases testosterone levels and prostate weight without altering $\mathrm{LH}$, prostate $5 \alpha$-reductase or steroid actue regulatory peptide levels in adult male Sprague-Dawley rats. Journal of Endocrinology 170 591-599.

Yeung WSB, Guldenaar SEF, Worley RTS, Humphreys J \& Pickering BT 1988 Oxytocin in Leydig cells: an immunocytochemical study of Percoll-purified cells from rat testes. Cell and Tissue Research 156 223-229.

You L, Casanova M, Bartolucci EJ, Fryczynski MW, Dorman DC, Everitt JI, Gaido KW, Ross SM \& Heck HA 2002 Combined effects of dietary phytoestrogen and synthetic endocrine-active compound on reproductive development in Sprague-Dawley rats: genestein and methoxyclor. Toxicological Sciences 66 91-104.4.

Received 4 April 2006

First decision 31 May 2006

Revised manuscript received 7 July 2006

Accepted 13 September 2006 